\title{
FSN-EN 0010
}

BIOACCUMULATION OF HEAVY METALS IN FRESHWATER Clarias anguillaris AND Parachanna Africana from LAKE GERIYO IN YOLA, NIGERIA

\author{
JONATHAN B.Y. ${ }^{1}$, MAINA H. M. ${ }^{2}$, MUSA Y. M. ${ }^{3}$ \\ ${ }^{1}$ Federal College of Freshwater Fisheries Technology, Maiduguri, Borno State \\ ${ }^{2}$ Department of Chemistry, Federal University of Technology, Yola \\ ${ }^{3}$ National Institute for Freshwater Fisheries Researcher, New-Bussa, Niger State
}

Copyright 2010, Fisheries Society of Nigeria.

This paper was prepared for presentation at the $25^{\text {th }}$ Annual International Conference and Exhibition in Administrative Staff College of Nigeria (ASCON), Topo-Badagry, Lagos, Nigeria, $25^{\text {th }}-29^{\text {th }}$ October, 2010.

This paper was selected for presentation by an FISON Program Committee following review of information contained in an abstract submitted by the author(s). Contents of the paper, as presented, have not been reviewed by the Fisheries Society of Nigeria and are subject to correction by the author(s). The material, as presented, does not necessarily reflect any position of the Fisheries Society of Nigeria, its officers, or members. Papers presented at FISON meetings are subject to publication review by Editorial Committees of the Fisheries Society of Nigeria. Electronic reproduction, distribution, or storage of any part of this paper for commercial purposes without the written storage of any part of this paper for commercial purposes without the written consent of the Fisheries Society of Nigeria is prohibited. Permission to reproduce in print is restricted to an abstract of not more than 300 words; illustrations may not be copied. The abstract must contain conspicuous acknowledgement of where and by whom the paper was presented. Write Librarian, Fisheries Society of Nigeria (FISON), P. O. Box 2607 Apapa,
Lagos.

\section{ABSTRACT}

This study was carried out to determine the bioaccumulation of heavy metals in Clarias anguillaris and Parachanna africana from Lake Geriyo Yola, Nigeria using energy dispersive $X$-ray fluorescence (EDXRF) spectrophotometer.. The results in $(\mathrm{mg} / \mathrm{kg}$, dry weight) showed different levels of $\mathrm{Cr}, \mathrm{Cu}, \mathrm{Mn}, \mathrm{Fe}, \mathrm{Ni}, \mathrm{Zn}$, and $\mathrm{Pb}$ in the two fish species. The order of heavy metals accumulated by $C$. anguillaris and $P$. africana are $\mathrm{Cr}>\mathrm{Fe}>\mathrm{Zn}>$ $\mathrm{Mn}>\mathrm{Cu}>\mathrm{Ni}>\mathrm{Pb}$ and $\mathrm{Ni}>\mathrm{Fe}>\mathrm{Zn}>\mathrm{Cu}$ respectively. The levels of $\mathrm{Cr}, \mathrm{Mn}$ and $\mathrm{Ni}$ in $C$. anguillaris and in $N i$ in $P$. africanawere higher than WHO and FEPA recommended maximum permissible limits (MPL) in fish, while the levels of $\mathrm{Zn}$, $\mathrm{Cu}$ and $\mathrm{Pb}$ were below the standards. The results suggest that Lake Geriyo has high pollution loads of these heavy metals in fishes and could pose a health hazards to man. Consequently, close monitoring of heavy metal loads in Lake Geriyo is recommended with a view to minimizing the risks to health of the population that depend on the lake for their water and fish supply.

\author{
Keywords: Heavy Metals, \\ Bioaccumulation, Lake Geriyo, $C$. \\ anguillaris, P.africana, Nigeria.
}

\section{INTRODUCTION}

The accumulation of heavy metals by aquatic biota has become a problem of increasing concern. Fish has the ability to accumulate heavy metals to hazardous levels with visible sign in the aquatic environments (Fostner et al., 1981)

Anthropogenic activities such as mining operations, petroleum exploration, and agricultural practices, industrial and municipal wastes have increased the concentrations of heavy metals in the lakes, rivers and stream which have caused concern regarding heavy metal bioaccumulation and human health hazards (Forstner et al., 1981). Bioaccumulation has been reported by several authors (Mathis and Cummings, 1973; Alabaster and Lloyd, 1980, Biney et al., 1991).

All heavy metals are potentially harmful when consumed above the recommended standard limits. At low concentrations, Cd, $\mathrm{As}, \mathrm{Pb}$ and $\mathrm{Hg}$ are toxic and they compete for sites with essential metabolites, replacement of essential ions, reactions with-SH groups of Adenosine Diphosphate (ADP) and Adenosine Triphosphate (ATP) (Alloway and Ayres, 1993).

This study was carried out to determine the bioaccumulation of heavy metals by fishes which are associated with potential health hazards to man. 


\section{MATERIALS AND METHODS}

Lake Geriyo is located at the out - skirts of Jimeta, in Yola metropolis (longitude $12^{0} 25^{\prime} \mathrm{E}$ and between latitude $9^{0} 8^{\prime} \mathrm{N}$ and $\left.9^{0} 17^{\prime} \mathrm{E}\right)$. The lake is a natural one that started as a small gulley, but was later expanded and filled with water from the rains and some influx from River Benue. The lake has been subjected to intense irrigation and it is a center for metal scraps market (UBRBDA, 1985).

\section{Sample Collection}

Two fish species (5 - 10 individuals of each species) namely, $C$.

anguillaris measuring $40.57 \square 1.30 \mathrm{~cm}$ and weighing $\quad 1000.30 \square 30.71 \mathrm{~g} \quad$ and $P$. africana $35.56 \square 1.29 \mathrm{~cm}$ and weighing $567.20 \square 15.21 \mathrm{~g}$ were procured from the local fishermen on the bank of the lake, during the month of April 2007. They were thereafter stored in a plastic cooler with ice flakes.

\section{Sample Preparation of Fish}

The two species of fish were oven dried to constant weight at $105{ }^{\circ} \mathrm{C}$. The dried samples were ground to powder and quartered to give representative sample weight. $0.5 \mathrm{~g}$ of the powdered fish samples was weighed and three drops of organic binder were added to each and were pressed with 10 tons hydraulic press to form pellet of each fish samples. Three replicate of pellets of each fish sample were prepared.

Determination of Heavy Metals in Fish by Energy Dispersive X- Ray Fluorescence (EDXRF)

The heavy metals in fish sample were determined using the modified version of Emission Transmission (E-T), Kump, (1996), Angeyo et al., (1998) and Funtua (1999). The pellet of each fish sample was put into $\mathrm{X}$-ray fluorescence spectrophotometer sample holder and it was bombarded with high energy electrons of ${ }^{109} \mathrm{Cd}(22.1 \mathrm{kev})$. Fluorescent $\mathrm{X}$-rays was produced which passes to the silicon lithium detector, through $M o$ target as a source of monochromatic $\mathrm{X}$-rays. The spectrum of energy generated on the detector was processed to obtain analytical data.

The intensity of the fluorescent x-rays on the detector would be proportional to the concentration of the individual element of interest in the sample.

\section{RESULTS AND DISCUSSION}

The mean concentrations of heavy metals in two species of fish from Lake Geriyo $(\mathrm{mg} / \mathrm{kg}$, dry weight) and that of water in $(\mathrm{mg} / \mathrm{l})$ and set standards are shown in Table I. $\mathrm{Cu}$ values ranged from $1.44 \square 0.06$ $\mathrm{mg} / \mathrm{kg}$ to $2.65 \square 0.05 \mathrm{mg} / \mathrm{kg}$ and it was recoded in both species. $\mathrm{Cr}$ value was $21.4 \square 0.6 \mathrm{mg} / \mathrm{kg}$ and it occurred in $C$. anguillaris. It was the most accumulated. $\mathrm{Cr}$ and $\mathrm{Cu}$ in the two fishes could $\mathrm{b}$ e attributed to the fact that chemicals made from salts of arsenic, chromium and copper mixed soluble formation (as copper-chronic-arsenate preservative) being used to prevent fungi and pest attack which provide a potential source of chemical spills and drainage within the catchments area of the lake (forstner et al, 1981) $\mathrm{Ni}$ values ranged from $1.11 \square 0.01$ $\mathrm{mg} / \mathrm{kg}$ to $7.12 \square 0.01 \mathrm{mg} / \mathrm{kg}$ and it occur in both fishes. $\mathrm{Pb}$ value was $1.06 \square 0.06$ $\mathrm{mg} / \mathrm{kg}$ it was the least and it was present in $C$. anguillaris only. $\mathrm{Pb}$ and $\mathrm{Ni}$ presence in the lake could be attributed to the fact that they are naturally found in surface waters due to weathering of minerals and soil erosions (USEPA, 1997). It could also be due to auto exhaust and phosphate fertilizers. Mn value $3.17 \square 0.02 \mathrm{mg} / \mathrm{kg}$, and it was found in C. anguillaris only. $\mathrm{Zn}$ values ranged from $4.13 \square 0.02 \mathrm{mg} / \mathrm{kg}$ to $6.04 \square 0.06 \mathrm{mg} / \mathrm{kg}$ and it was present in $C$. anguillarisand $P$. africana. $\mathrm{Cr}, \mathrm{Cu}, \mathrm{Zn}$ and $\mathrm{Mn}$ are concentrated in the sediments of lakes and rivers as well as in aerobic and anaerobic bacteria. $C$. anguillaris and $P$. africanaare bottom feeders, they therefore concentrate $\mathrm{Mn}, \mathrm{Zn}$ from sediments and bacteria as well as in fertilizers (Shahunthala, 1989). 
$\mathrm{Fe}$ values ranges from $5.7 \square 1.3 \mathrm{mg} / \mathrm{kg}$ to $9.45 \square 0.13 \mathrm{mg} / \mathrm{kg}$ was detected in $P$. africana and C. anguillaris.

It could be due to metal works, run-of from rusted metallic pipes and the dumping of metal scraps from metal scraps market on the bank of lake Geriyo.

The levels of $\mathrm{Cr}, \mathrm{Mn}$ and $\mathrm{Ni}$ are higher when compared with WHO and FEPA standard limits and the consumption of these fishes could cause health hazards to man. The leve; s of $\mathrm{Cu}, \mathrm{Zn}$ and $\mathrm{Pb}$ are lower than WHO and FEPA in the fishes and it could be due to the fact that $\mathrm{Cu}$ and $\mathrm{Zn}$ have least value in water (Table 1). Similarly the levels of $\mathrm{Cr}, \mathrm{Mn}, \mathrm{Ni}, \mathrm{As}$ in water of the lake are higher than WHO and FEPA and the water is considered unsuitable for drinking and aquaculture.

\section{CONCLUSION}

Therefore, Lake Geriyo is contaminated with $\mathrm{Cr}, \mathrm{Mn}$, and $\mathrm{Ni}$; consequently the fish species $C$ anguillaris and $P$. africana were contaminated with varying level of $\mathrm{Cr}, \mathrm{Mn}$, and Ni. The lake has been subjected to intense irrigation and pollution loads coming up stream of river benue during the rainy season to the lake is a major factors for high heavy metal levels in the lake and fishes.

\section{ACKNOWLEDGEMENT}

I want to express my profound gratitude to Prof. B.M.B. Ladu of Federal University of Technology Yola and Dr. Femi Daddy Provost, Federal College of Freshwater Fisheries Technology, Baga Maiduguri for their encouragement and unwavering support. I also want thank the laboratory technologist at Energy research Zaria for analyzing the samples.

\section{REFERENCES}

Alloway, B. J., Ayres, D. C. (1993). Chemical Principles of Environmental Pollution. Blackie Academic and Professional London. Glasgow, U. K. Pp 140-149.
Alabaster, J. S. and Lloyd R. (1980). Water quality criteria for fish ( $2^{\text {nd }}$ ed) London Butterworths.

Angeyo, K. H., Patel, J. P., Mangaia, J. M. and Naraya D. G. S. (1998). Optimization of X-ray fluorescence Elemental Analysis: an example from Kenyan. Appl. Radiat. Isot. 49:885-891.

Biney CA. Amuzu AT. Calaman D. Kaba N. Naeve H. Saad MAH (1991). Review of heavy metals in the African Aquatic Environment Ecotoxical Environ. Saf. 8:134-159; F.A.O Fish Rep (471):7-43.

Federal Environmental Protection Agency (2003) Guidelines and Standards for Environmental Control in Nigeria pp 238.

Forstner U. Wittman GTW (1981). Metal Pollution in aquatic Environment. Spring Verlag Berlin, Heidesberg, New york pp 386.

Funtua, I. I. (1999). Application of the Transmission-Emission Method in EDXRE for the Determination of Trace Elements in Geological and Biological Material J. Trace Microprobe Tech 17, 293-297.

Kump. P. (1996). Quantitative Analysis of Environmental samples (QAES) Instruction manual, Ljublijana.

Mathis, B. J.,and Cummings TF (1973). Selected metals sediment, water and biota in the Illinois River J. Wat. Pollut. Cont. Fed 45:1573-1583.

Shahunthala D. (1989) Heavy metal levels in Malaysian fish. Fisheries Bulletin.

Upper Benue River Basin Development Authority (1985)

United States Environmental Protection Agency (1997). Water Prevention and Conservation EPA. 905-F-97-011-August 1997.

World Health Organization (1985). Guidelines for drinking water quality. Recommendation WHO General 130pp 
Table 1: Mean concentration of Heavy Metals in fish ( $\mathrm{mg} / \mathrm{kg}$, dry weight) from Lake Geriyo and set Standards. WHO (1985) and FEPA (2003)

\begin{tabular}{|c|c|c|c|c|}
\hline \multirow{2}{*}{$\begin{array}{l}\text { Heavy } \\
\text { Metals }\end{array}$} & \multicolumn{2}{|l|}{ Fish samples } & \multirow{2}{*}{$\begin{array}{l}\text { WHO } \\
1985\end{array}$} & \multirow{2}{*}{$\begin{array}{l}\text { FEPA } \\
2003\end{array}$} \\
\hline & C. anguillaris & P. africana & & \\
\hline $\mathrm{Cr}$ & $21.400 \square 0.600$ & BDL & 0.15 & 0.15 \\
\hline $\mathrm{Cu}$ & $1.440 \square 0.060$ & $2.650 \square 0.050$ & 3 & $1-3$ \\
\hline $\mathrm{Mn}$ & $3.710 \square 0.020$ & $\mathrm{BDL}$ & 0.5 & 0.5 \\
\hline $\mathrm{Fe}$ & $9.450 \square 0.130$ & $5.700 \square 1.300$ & N.S & N.S \\
\hline $\mathrm{Ni}$ & $1.110 \square 0.010$ & $7.120 \square 0.010$ & 0.6 & 0.5 \\
\hline $\mathrm{Zn}$ & $6.040 \square 0.060$ & $4.130 \square 0.020$ & $10-75$ & 75 \\
\hline $\mathrm{Pb}$ & $1.060 \square 0.060$ & BDL & 2.0 & 2.0 \\
\hline
\end{tabular}

BDL: Below Detectable Limits N.S: Not specified. $\square$ : Standard deviation. 